\title{
A survey of hematologists on compulsory health service in Turkey
}

\section{Türkiye'de zorunlu hizmet görevi yapan hematoloji uzmanlarnna yönelik bir anket çalışması}

\author{
Zeynep Arzu Yeğin 1 , Mutlu Arat ${ }^{2}$ \\ ${ }^{1}$ Department of Hematology, Konya Education and Research Hospital, Konya, Turkey \\ ${ }^{2}$ Department of Hematology, Istanbul Bilim University, İstanbul, Turkey
}

\section{To the Editor}

The quality of health care is closely related to the level of physician job satisfaction, which depends on several factors, including working conditions, income, hospital resources and workload [1-3]. Compulsory health service was instituted by the Turkish Ministry of Health in 2005 (www.saglik.gov.tr), which is a postgraduate program that requires practitioners and specialists to work 300-600 days in underserved regions of the country.

This nationwide survey was conducted in 2010 by the Turkish Hematology Society in order to investigate lifestyle, working conditions, and job satisfaction among hematologists fulfilling their compulsory health service. The survey included 2 sections for collecting social and professional data. The primary results of the survey are detailed in the Table.

In all, 15 hematologists (male/female: 9/6; age range: 33-40 years; married/single: 11/4) from 11 cities (Adana, Ankara, Antakya, Bursa, Diyarbakır, Erzurum, Gaziantep, İstanbul, Konya, Şanlıurfa, and Trabzon) were asked to complete a 33-item electronic survey comprised of general questions con- cerning the social and professional circumstances in the region in which they were working.

Social and financial dissatisfaction rate among the respondents were reported to be $40 \%$ and $60 \%$ respectively. The overall job satisfaction rate was $66.7 \%$. Among the 15 respondents, 6 (40\%) were confronted with verbal/physical violence by patients and/or coworkers at least once. This is a remarkable issue which might represent a common fact for a particular group of physicians working in similar conditions. Additionally, $26.7 \%$ of the respondents experienced social adaptation problems. Consequently, job dissatisfaction among the hematologists should not be underestimated as it might cause an adverse impact on patient care as well. In consideration of inappropriate physical conditions and inadequate diagnostic resources, approximately $45 \%$ of patients are directed to larger centers, which is not consistent with the primary goal of compulsory health service.

The respondents were asked to evaluate the quality of hospital resources. The main defects were notified in laboratories, blood banks, and histopathology departments. As a result, hematologists 
Table 1. The Primary Social and Professional Problems Reported by Hematologists

\begin{tabular}{ll}
\hline Social/Professional Problems & $\begin{array}{l}\text { Frequency } \\
\text { (n=15) }\end{array}$ \\
\hline Insufficient laboratory resources & $14(93.3 \%)$ \\
\hline Insufficient blood bank resources & $13(86.7 \%)$ \\
\hline Insufficient histopathologic evaluation & $13(86.7 \%)$ \\
\hline Difficulty with academic productivity & $12(80 \%)$ \\
\hline Difficulty referring patients to other hospitals & $7(46.7 \%)$ \\
\hline Exposure to verbal/physical violence & $6(40 \%)$ \\
\hline Social dissatisfaction & $6(40 \%)$ \\
\hline $\begin{array}{l}\text { Difficulty communicating with patients } \\
\text { due to language diversity }\end{array}$ & $5(33.3 \%)$ \\
\hline Difficulty attending scientific activities & $5(33.3 \%)$ \\
\hline
\end{tabular}

seemed to treat predominantly benign hematologic disorders like iron deficiency anemia. This primary step health service with inadequate clinical practice and scientific efficiency causes a professional deterioration that decreases the scientific productivity as well. Optimum working conditions should be adjusted in order to overcome this obstacle.

In conclusion, the results of our survey highlight the main social and professional problems experi- enced by Turkish hematologists performing compulsory health service. Hematologists would display a better performance in patient care and academic course underneath more favorable infrastructure and working conditions. Strategies are urgently needed to ensure job satisfaction among hematologists on compulsory heath service.

\section{Conflict of interest statement}

The authors of this paper have no conflicts of interest, including specific financial interests, relationships, and/or affiliations relevant to the subject matter or materials included.

\section{References}

1. Wada K, Arimatsu M, Higashi T, Yoshikawa T, Oda S, Taniguchi H, Kawashima M, Aizawa Y. Physician job satisfaction and working conditions in Japan. J Occup Health 2009;51:261-6. [CrossRef]

2. Deshpande SP, DeMello J. An empirical investigation of factors influencing career satisfaction of primary care physicians. J Am Board Fam Med 2010;23:762-9. [CrossRef]

3. Magnavita N, Fileni A, Bergamaschi A. Satisfaction at work among radiologists. Radiol Med 2009;114:1330-44. [CrossRef] 